\title{
Managing geohazard risk during mineral exploration at remote locations in rugged terrain and tropical environments
}

\author{
J Whittall BGC Engineering Inc., Canada \\ P Quinn BGC Engineering Inc., Belgium \\ M Lato BGC Engineering Inc., Canada \\ M Porter BGC Engineering Inc., Canada \\ B Bowden Rio Tinto Exploration Pty Ltd, Australia \\ J Drew Rio Tinto Exploration Pty Ltd, Australia \\ M Croaker Rio Tinto Exploration Pty Ltd, Australia
}

\begin{abstract}
Mineral exploration projects in tropical environments can be exposed to a range of geohazards, including landslide, rockfall, debris flow, flooding, and subsidence. Understanding the geohazard types present, and their potential consequences at a proposed drill pad or camp site, is critical to managing the project's geohazard risks. During the early stages of exploration, typical datasets used to map and evaluate geohazards, such as stereo airphotos and airborne LiDAR data, are often not available; as a result, engineers and geologists must rely on reconnaissance-level desktop studies and field observations of the geomorphology to estimate the risk of geohazard exposure. In order to effectively estimate geohazard risk at individual sites in a systematic manner, an evidence-based system was developed employing a standard risk equation. The components of the field-based geohazard risk assessment system include identifying the geohazard type and estimating the annual probability of occurrence at a specific location, estimating the spatial probability of the geohazard reaching the elements at risk, estimating the vulnerability of the elements at risk to the geohazard, and estimating the temporal probability that the elements at risk would be present when a geohazard occurs.

This approach enables credible geohazard threats to be rated and facilitates appropriate risk management approaches suitable for each location and geohazard type. In parallel with the geohazard risk ratings, geohazard risk can be managed through more detailed assessment, awareness training, engineering measures, relocation of drill sites and infrastructure, and trigger action response plans. This paper presents a case study that employs the methodology at a greenfield exploration project site in tropical jungle in mountainous terrain.
\end{abstract}

Keywords: risk assessment, exploration, geohazards, tropical environment

\section{Introduction}

Mineral exploration projects involve personnel travelling through and occupying previously undeveloped terrain. These sites can be exposed to geological hazards (geohazards) such as landslides and hydrologic processes that may pose a safety risk to workers and a variety of other consequences. Like any work site, workers at exploration sites and the local stakeholders need to understand the geohazard risks associated with the project. During the early stages of exploration, preferably before personnel are stationed at the site, geohazard risk assessments are a valuable tool to better understand credible geohazard threats and to help plan the exploration program accordingly. This paper provides field-tested methodology and guidance for conducting geohazard risk assessments at greenfield exploration sites in tropical, mountainous terrain. 


\section{Geohazard risk concepts}

Risk can be defined as expected loss and may be estimated in different ways (Leroi et al. 2005). The optimum nature of risk evaluation and presentation depends on the decisions to be supported by its outcome. Commonly, resource development companies develop risk matrices to provide a standardised comparison of risks across asset types and contexts. These matrices are often semi-quantitative, where quantitative inputs are used to the extent they are available and meaningful, and the output is assigned into one of several bins or qualitative categories (Porter et al. 2019).

A key notion of risk is that it is a probabilistic measure, and as such, its formulation requires accounting for all the linkages and probabilities of all chains of events that could lead to a negative outcome. Risk is usually estimated as a combination of the annual likelihood of a threat occurring (a geohazard) and the consequence that results (Morgenstern 1995). The key components of geohazard risk are:

- A geohazard of a given magnitude must occur.

- The geohazard must reach a location where it can impact an element(s) at risk.

- The element(s) at risk must be present at the time when the geohazard occurs or must encounter the geohazard in a way that impact cannot be avoided.

- The way the geohazard impacts the element(s) at risk, or the way the element(s) at risk impact the geohazard, must be sufficient to cause some degree of loss that ranges from no loss to complete loss.

- The element(s) at risk must have some value. Often this is the number of people exposed, the potential financial loss, schedule impact, environmental effect, or damage to corporate reputation.

A given location may be exposed to numerous geohazards of different types. Similarly, a person travelling between sites, or occupying more than one site during their work may be exposed to a set of geohazards at the original location, a different set of geohazards during the traverse, and a third set of geohazards at the destination. The cumulative risk associated with exposure to numerous geohazards may be significantly higher than that for a particular geohazard or an individual site.

\section{$3 \quad$ Methodology}

This paper provides a semi-quantitative approach to assigning hazard and consequence ratings, and then aligns these ratings to a risk category. The key steps to establishing this rating are described in the following subsections, and can be summarised as:

1. Identify credible geohazard types.

2. Evaluate the hazard rating.

3. Get clear on the use and occupancy of the sites.

4. Evaluate the consequence rating.

5. Assign a risk rating.

6. Evaluate risk management options in context of corporate policies and risk tolerance criteria. 


\subsection{Credible geohazard types}

Geohazards are first prescribed to each site by assessing whether they could credibly occur through a desktop study, and then their potential occurrence is refined during a field reconnaissance. At a screening level, each geohazard type has particular defining features that are used for field-based identification. For example, the following typical range of geohazards might be deemed credible based on observation of the associated features:

- Rockfall: presence of rock outcrop, rock debris, or boulders on the slope above the site.

- Shallow landslide: slope angle; proximity to potentially weak, unstable material at geologic contacts or faults; proximity to scarps; proximity to a colluvium slope in satellite imagery; or observations of loose material in the reconnaissance notes. Features above, below or across the site may be pertinent.

- Deep-seated landslide: scarps, tension cracks, sag ponds, toe bulges, colluvium in satellite imagery.

- Flooding and debris flows: near proximity to streams or steep gullies; damaged or sparse vegetation.

- Subsidence: proximity to mapped vents, sink holes, volcanic plugs and artisanal mining. Observation of depressions on the surface, openings to underground mine workings or presence of waste rock piles.

Geology reports, regional scale mapping, topography (digital elevation model (DEM)), satellite imagery, and publicly available earthquake and climate data are useful screening level tools. Ideally high-resolution DEMs generated from LiDAR survey are used, but often these are not available at early stages of exploration.

\subsection{Hazard evaluation}

Hazard encounter probability $(\mathrm{H})$ (or the likelihood of occurrence of a potentially harmful phenomenon) is the annual probability of a geohazard occurring and reaching a site. $\mathrm{H}$ is determined as the product of the estimated temporal probability of a geohazard event occurring, $\mathrm{P}(\mathrm{H})$, with the conditional probability of the geohazard reaching the access trail, work site, or camp site, $\mathrm{P}(\mathrm{S}: \mathrm{H})$, given the occurrence of the geohazard. The output of the hazard matrix in Table 1 is a semi-quantitative classification of the annual probability of a given geohazard occurring and reaching a given site, or $\mathrm{H}$.

Table 1 Example hazard matrix for exploration sites developed by the authors

\begin{tabular}{|c|c|c|c|c|c|c|}
\hline \multicolumn{4}{|c|}{$\begin{array}{l}\text { Geohazard probability: } \\
\text { Annual probability of geohazard occurring, } \mathrm{P}(\mathrm{H})\end{array}$} & \multirow{2}{*}{\multicolumn{3}{|c|}{$\begin{array}{l}\text { Hazard or likelihood } \\
\text { Annual probability of a geohazard } \\
\text { occurring and reaching a site, } \mathrm{H}\end{array}$}} \\
\hline \multirow{2}{*}{$\begin{array}{l}\text { Descriptor } \\
\text { Very high }\end{array}$} & \multirow{2}{*}{ 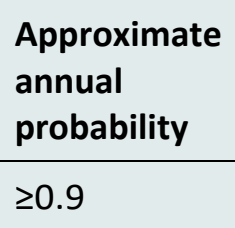 } & \multirow{2}{*}{$\begin{array}{l}\text { Approximate } \\
\text { annual } \\
\text { frequency } \\
\geq 2\end{array}$} & \multirow{2}{*}{$\begin{array}{l}\begin{array}{l}\text { Return } \\
\text { period } \\
\text { (years) }\end{array} \\
<0.5\end{array}$} & & & \\
\hline & & & & Possible & Likely & Almost certain \\
\hline High & 0.5 to $<0.9$ & 1 to $<2$ & $>0.5$ to 1 & Unlikely & Possible & Likely \\
\hline Moderate & 0.1 to $<0.5$ & 0.1 to $<1$ & 1 to 10 & Rare & Unlikely & Possible \\
\hline Low & 0.01 to $<0.1$ & 0.01 to $<0.1$ & 10 to 100 & Rare & Rare & Unlikely \\
\hline Very low & $<0.01$ & $<0.01$ & $>100$ & Very rare & Rare & Rare \\
\hline Conditional & bability of geoh & zard reaching $\mathrm{t}$ & e site, $P(S: H)$ & Very low & Moderate & Very high \\
\hline
\end{tabular}

The annual probability of a geohazard occurring is divided in this study into five categories, as presented on the vertical axis of Table 1. Estimation of $\mathrm{P}(\mathrm{H})$ is determined based on field observations ranging from a geohazard actively occurring to regional terrain attributes that may indicate hazard potential (Table 2). The inspector determines the presence or absence of relevant attributes and the number of observations in each category is used to guide the inspector in selecting $\mathrm{P}(\mathrm{H})$ according to Table 3. 
Table 2 Field observations used to select $\mathrm{P}(\mathrm{H})$

Category 1 - Active or measured hazard near site; choosing one or more indicates $P(H) \geq 0.9$; very high

Measured/observed, ongoing/very recent (weeks to a few months) ground movement or flooding (site located in channel): yes $\square$ no $\square$

Other evidence of impending failure $\square$; details:

Category 2 - Evidence of recent hazard activity near site; choosing one or more indicates $P(H) \geq 0.1$; moderate or high

Tension cracks $\square$

Fresh landslide scarps/detachment scars $\square$

Site located on active floodplain $\square$

Impact marks on ground $\square$

Fresh blocks near site $\square$

Recent/fresh levees along stream $\square$

Other similar observations $\square$;
Freshly exposed soil/rock $\square$

Fresh debris on slope, at slope toe, in trees or in gullies $\square$

Fresh rockfall scars on trees $\square$

Broken or damaged vegetation $\square$

Subsurface erosion/voids/sinkholes $\square$

Recent/fresh debris deposit on fan $\square$

Category 3 - Evidence of older hazard activity near site; choosing one or more indicates $P(H) \geq 0.01$; low (or higher)

Excavation of slope toe $\square$

Deposition at slope crest $\square$

Fill loading near site $\square$

Overgrown landslide scarps/detachment scars $\square$

Bedrock joint dilation $\square$

Graben topography $\square$

Unstable source material upslope $\square$

Vegetation (e.g. lichen) covered blocks near site $\square$

Healed scars on trees $\square$

Significant removal of vegetation in last five years $\square$

Overgrown/old debris deposit on fan $\square$

Site located on floodplain $\square$

Tilted or deformed vegetation $\square$

Ponded water on slope $\square$

Water directed onto site $\square$

Disrupted or altered surface drainage $\square$

Surface water infiltration $\square$

Active river erosion of slope toe $\square$

Active rill and/or gully erosion $\square$

Overgrown/old levees along stream $\square$

Other similar observations $\square$; details:

Category 4 - Terrain attributes near site that may indicate hazard potential; choosing one or more indicates $\mathbf{P}(\mathrm{H}) \geq 0.001$; very low (or higher)

Fill placed on slope $>3 \mathrm{~m}$ thick $\square$

Landslide(s) in the area $\square$

Highly weathered bedrock or soil $\square$

Erodible soil $\square$

Adversely oriented bedrock structure $\square$

Collapsible soil $\square$

Hummocky ground $\square$

Groundwater seeps or springs $\square$

Scree slope or colluvial apron $\square$

Site is within stream or on fan $\square$

Vegetated/old debris on slope $\square$

Ponded water on the adjacent uplands $\square$

Nearby irrigation $\square$

Other similar observations $\square$; details:

Presence of alluvial/colluvial fan $\square$

Category 5 - Regional terrain attributes that may indicate hazard potential; choosing one or more indicates $\mathrm{P}(\mathrm{H}) \geq 0.0001$; very low (or higher)

Gullied topography $\square$

Slope $>10^{\circ} \square$

River at the toe of the slope $\square$

Historical underground mining $\square$

Bedrock dissolution/karst $\square$
Stepped/benched slope $\square$

Clay or silt rich soil $\square$

Vents or volcanic plugs $\square$

Agriculture near pad $\square$

Construction nearby in last two years $\square$ 
Table 3 Guidance for aggregating field observations into $\mathrm{P}(\mathrm{H})$ selections

\begin{tabular}{|c|c|c|c|c|c|c|c|}
\hline \multirow[t]{2}{*}{$\begin{array}{l}\text { Annual geohazard } \\
\text { probability, } \mathrm{P}(\mathrm{H})\end{array}$} & \multirow{2}{*}{$\begin{array}{l}\text { Return } \\
\text { period } \\
\text { (years) }\end{array}$} & \multirow{2}{*}{$\begin{array}{l}\text { Annual } \\
\text { frequency } \\
\text { range }\end{array}$} & \multicolumn{5}{|c|}{$\begin{array}{l}\text { Guidance for } \mathrm{P}(\mathrm{H}) \text { selection } \\
\text { (number of observations of each category) }\end{array}$} \\
\hline & & & Cat 1 & Cat 2 & Cat 3 & Cat 4 & Cat 5 \\
\hline Very low, $\mathrm{P}(\mathrm{H})<0.01$ & $>100$ & $<0.01$ & 0 & 0 & 0 & $>1$ & - \\
\hline Low, $\mathrm{P}(\mathrm{H}) 0.01$ to 0.1 & 10 to 100 & 0.01 to $<0.1$ & 0 & 0 & $>1$ & - & - \\
\hline Moderate, $\mathrm{P}(\mathrm{H}) 0.1$ to 0.5 & 1 to 10 & 0.1 to $<1$ & 0 & 1 or 2 & - & - & - \\
\hline High, $P(H) 0.5$ to 0.9 & 0.5 to 1 & 1 to $<2$ & 0 & $\geq 3$ & - & - & - \\
\hline Very high, $P(H) \geq 0.9$ & $<0.5$ & $\geq 2$ & $\geq 1$ & - & - & - & - \\
\hline
\end{tabular}

Table 3 is intended to guide the inspector in choosing the appropriate category for $P(H)$. If the guidance does not agree with the inspector's field judgement, a different category can be selected provided the evidence used to form that judgement is recorded, and subsequently used to improve the process by calibrating the guidance in Table 1 for local experience.

$\mathrm{P}(\mathrm{H})$ for flooding hazard is based on the location of the site within the bankfull width, active floodplain, or floodplain of the watercourse (Figure 1).

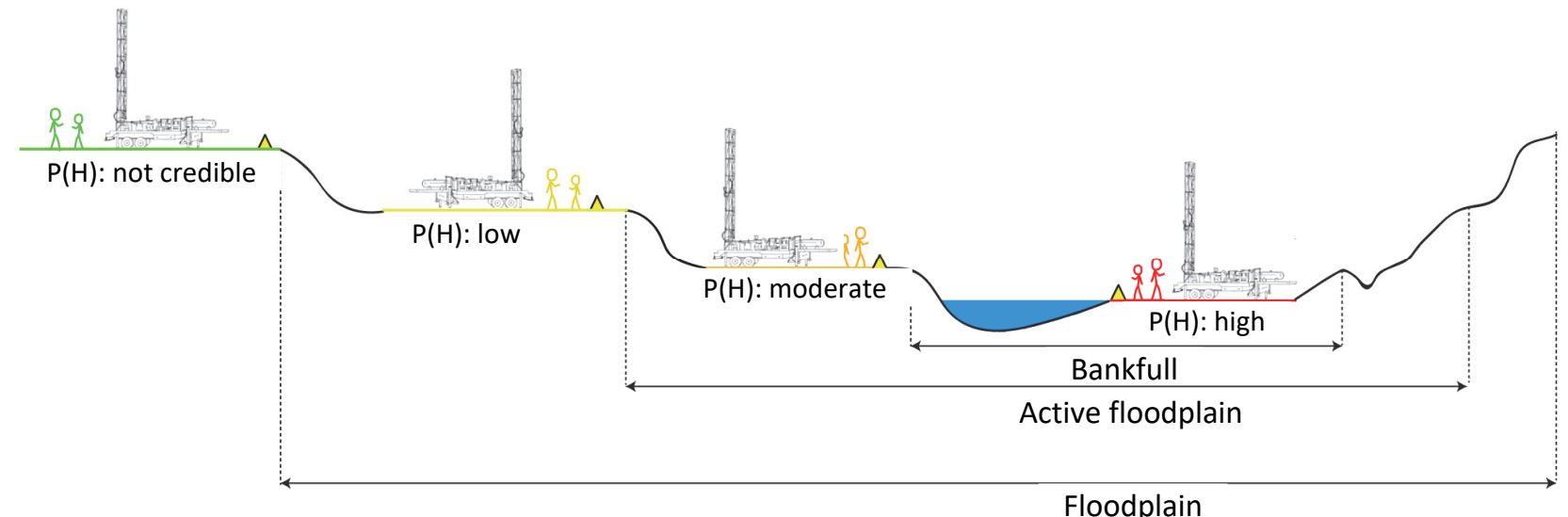

Figure 1 Hazard guidance to select $\mathrm{P}(\mathrm{H})$ category for flooding hazards

The conditional probability of a geohazard reaching the site, $\mathrm{P}(\mathrm{S}: \mathrm{H})$, is divided into three order of magnitude probability categories, as presented on the horizontal axis of Table 1 . Selecting an appropriate $\mathrm{P}(\mathrm{S}: \mathrm{H})$ is based on the proximity of the geohazard to the site, and in the case of rockfalls and shallow landslides, is based on the shadow angle and fahrböschung angle (Heim 1932) concepts. Guidance for estimating P(S:H) for each geohazard type is provided in Tables 4 through 8. 
Table 4 Rockfall and upslope shallow landslide hazard guidance to select $\mathrm{P}(\mathrm{S}: \mathrm{H})$ category

\begin{tabular}{lll}
\hline $\begin{array}{l}\text { Spatial probability, } \\
\mathbf{P}(\mathbf{S : H})^{1,2}\end{array}$ & $\begin{array}{l}\text { Representative } \\
\text { probability (unitless) }\end{array}$ & Criteria for selection \\
\hline Very low & $\sim 0.01$ & $\begin{array}{l}\text { Angle from upslope edge of site to highest, steepest } \\
\text { rockfall or landslide source }<20^{\circ}\end{array}$ \\
Moderate & $\sim 0.1$ & $\begin{array}{l}\text { Angle from upslope edge of site to highest, steepest } \\
\text { rockfall or landslide source } 20 \text { to } \leq 30^{\circ}\end{array}$ \\
Very high & $\sim 1$ & $\begin{array}{l}\text { Angle from upslope edge of site to highest, steepest } \\
\text { rockfall or landslide source }>30^{\circ}\end{array}$ \\
\hline
\end{tabular}

Note:

1. Very large rockfalls (rock avalanche) or debris slides may have higher mobility and could potentially be rated one category higher.

2. Consider using moderate or very high if there is evidence of deposits from past events reaching the site.

Table 5 Downslope shallow landslide hazard guidance to select $\mathrm{P}(\mathrm{S}: \mathrm{H})$ category

\begin{tabular}{lll}
\hline $\begin{array}{l}\text { Spatial probability, } \\
\mathbf{P ( S : H )}\end{array}$ & $\begin{array}{l}\text { Representative } \\
\text { probability (unitless) }\end{array}$ & Criteria for selection \\
\hline Very low & $\sim 0.01$ & $\begin{array}{l}\text { Crest of potentially unstable slope is more than } 15 \mathrm{~m} \\
\text { from the pad }\end{array}$ \\
Moderate & $\sim 0.1$ & $\begin{array}{l}\text { Crest of potentially unstable slope is between } 5 \text { to } 15 \mathrm{~m} \\
\text { from the pad }\end{array}$ \\
Very high & $\sim 1$ & $\begin{array}{l}\text { Crest of potentially unstable slope is } 5 \mathrm{~m} \text { or less from the } \\
\text { pad }\end{array}$ \\
\hline
\end{tabular}

Table 6 Flooding hazard guidance to select P(S:H) category

\begin{tabular}{lll}
\hline $\begin{array}{l}\text { Spatial probability, } \\
\text { P(S:H) }\end{array}$ & $\begin{array}{l}\text { Representative } \\
\text { probability (unitless) }\end{array}$ & Criteria for selection \\
\hline Very high & $\sim 1$ & $\begin{array}{l}\text { Spatial probability of occurrence is assumed for } \\
\text { flooding scenarios if a credible hazard is present }\end{array}$ \\
\hline
\end{tabular}

Table 7 Subsidence hazard guidance to select $\mathrm{P}(\mathrm{S}: \mathrm{H})$ category

\begin{tabular}{lll}
\hline $\begin{array}{l}\text { Spatial probability, } \\
\text { P(S:H) }\end{array}$ & $\begin{array}{l}\text { Representative } \\
\text { probability (unitless) }\end{array}$ & Criteria for selection \\
\hline Very low & $\sim 0.01$ & $\begin{array}{l}\text { Existing subsidence feature or mine openings }>50 \mathrm{~m} \\
\text { from site }\end{array}$ \\
& $\sim 0.1$ & $\begin{array}{l}\text { Existing subsidence feature or mine openings }>20 \mathrm{~m} \\
\text { from site }\end{array}$ \\
Moderate & $\sim 1$ & $\begin{array}{l}\text { Existing subsidence feature or mine openings }<20 \mathrm{~m} \\
\text { from site }\end{array}$ \\
\hline
\end{tabular}


Table 8 Site located on an active landslide hazard guidance for selecting P(S:H) category

\begin{tabular}{lll}
\hline $\begin{array}{l}\text { Spatial probability, } \\
\text { P(S:H) }\end{array}$ & $\begin{array}{l}\text { Representative } \\
\text { probability (unitless) }\end{array}$ & Criteria for selection \\
\hline Very high & $\sim 1$ & $\begin{array}{l}\text { Spatial probability of occurrence is assumed } \sim 1 \text { for sites on } \\
\text { landslide slope scenarios if a credible hazard is present }\end{array}$ \\
\hline
\end{tabular}

Access trails, work sites and camps on a landslide or a floodplain are categorised as having very high spatial probability due to their physical location intersecting the hazard's spatial extent.

The hazard class, $\mathrm{H}$, for all geohazard types is selected from the matrix in Table 1 based on the interpreted $\mathrm{P}(\mathrm{H})$ and $\mathrm{P}(\mathrm{S}: \mathrm{H})$ values, yielding values that range from very rare to almost certain.

\subsection{Establish the use and occupancy of the sites}

A key step is to understand the intended use, size and occupancy of each site. The number of people present, duration of each stay, and type and distribution of equipment all inform the consequence of the risk assessment. A camp, for example, likely has a larger and longer-term occupancy and footprint than a helicopter pad. By contrast, a smaller drill pad may have fewer occupants for a shorter duration but they are stationed on a more condensed footprint. Grouping sites with similar use and occupancy (roughly order of magnitude bins) allows the designation of simple consequence bins, such as:

- Momentary occupancy: e.g. access trails, field mapping locations.

- Low occupancy: e.g. helicopter pads, test pits, staging areas.

- Medium occupancy: e.g. drill pads, high occupancy staging areas.

- High occupancy: e.g. camps, other permanently occupied sites.

\subsection{Consequence assessment}

In assessing safety risk, a convenient simplification is to group the proposed sites into occupancy categories based on the temporal probability that a given number of elements at risk (i.e. workers) will be present and the vulnerability of those workers to the geohazard under consideration (Table 9). The vertical axis of the matrix considers geohazard velocity or impact intensity and a person's ability to recognise and avoid the geohazard. This is a proxy for vulnerability, which is the conditional probability of fatality should a worker be present when a geohazard occurs. Site use and occupancy (horizontal axis) reflect the temporal probability that one or more workers will be at the location impacted by the geohazard. The combination of vulnerability on the vertical axis, and exposure, as represented by temporal probability and number of workers present on the horizontal axis, provides an indication of the expected number of fatalities should a geohazard occur and reach a site. The consequence thus obtained is one of four descriptive categories which each represent approximately order of magnitude ranges for probability of a worker fatality. 


\section{Table 9 Example consequence matrix for exploration sites}

\begin{tabular}{|c|c|c|c|c|c|}
\hline \multirow{5}{*}{ 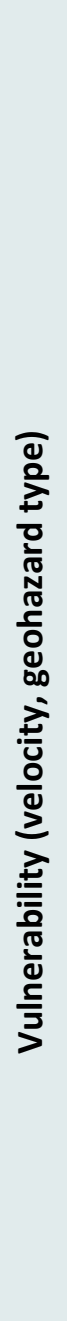 } & $\begin{array}{l}\text { Very high: } \\
\text { typically }>5 \mathrm{~m} / \mathrm{s} \text {; } \\
\text { e.g. large rockfalls, } \\
\text { debris slides } \\
\text { above site }\end{array}$ & Serious & Major & Major & Catastrophic \\
\hline & $\begin{array}{l}\text { High: typically } \\
>5 \mathrm{~m} / \mathrm{s} ; \text { e.g. small } \\
\text { rockfalls, debris } \\
\text { slides above site }\end{array}$ & Medium & Serious & Major & Major \\
\hline & $\begin{array}{l}\text { Moderate: } \\
\text { typically } 3 \mathrm{~m} / \mathrm{min} \\
\text { to } 5 \mathrm{~m} / \mathrm{s} \text {; e.g. } \\
\text { floods, debris } \\
\text { floods, landslides } \\
\text { below site }\end{array}$ & Minor & Medium & Serious & Major \\
\hline & $\begin{array}{l}\text { Low: typically } \\
<3 \mathrm{~m} / \mathrm{min} \text {; } \\
\text { e.g. subsidence, } \\
\text { earth creep, } \\
\text { erosion }\end{array}$ & Minor & Minor & Medium & Serious \\
\hline & & $\begin{array}{l}\text { Very low: minor } \\
\text { access trails, } \\
\text { outcrop mapping }\end{array}$ & $\begin{array}{l}\text { Low: helicopter } \\
\text { pads, } \\
\text { low occupancy } \\
\text { staging areas, } \\
\text { test trenching }\end{array}$ & $\begin{array}{l}\text { Medium: drill } \\
\text { pads, } \\
\text { high-occupancy } \\
\text { staging areas }\end{array}$ & $\begin{array}{l}\text { High: camps } \\
\text { and other } \\
\text { permanently } \\
\text { occupied sites }\end{array}$ \\
\hline & & \multicolumn{4}{|c|}{ Temporal probability and elements at risk } \\
\hline
\end{tabular}

Note:

Proposed consequence classes reflect estimates of the likely number of fatalities should a geohazard event occur and reach a site. Expected number of fatalities: catastrophic $\geq 1$, major $=0.1$ to 1 , serious $=0.01$ to 0.1 , medium $=0.001$ to 0.01, minor $=<0.001$.

\subsection{Risk assessment}

Risk ratings are assigned to each site (and to each geohazard if multiple geohazard types are present at an individual site) by aligning the hazard $(\mathrm{H})$ and consequence $(\mathrm{C})$ ratings in Table 10 . A particular risk level has an implied tolerability with clearly elaborated protocols for the general approach and urgency of required risk management measures. 
Table 10 Example risk matrix

\begin{tabular}{|c|c|c|c|c|c|c|}
\hline \multirow{8}{*}{ 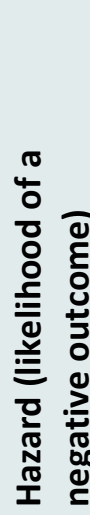 } & \multirow{4}{*}{$\begin{array}{l}\text { Almost certain } \\
\text { Likely }\end{array}$} & \multicolumn{5}{|c|}{ Consequence } \\
\hline & & Minor & Medium & Serious & Major & Catastrophic \\
\hline & & Moderate & High & Critical & Critical & Critical \\
\hline & & Moderate & High & High & Critical & Critical \\
\hline & Possible & Low & Moderate & High & Critical & Critical \\
\hline & Unlikely & Low & Low & Moderate & High & Critical \\
\hline & Rare & Low & Low & Moderate & High & High \\
\hline & Very rare & Low & Low & Low & Moderate & High \\
\hline
\end{tabular}

\subsection{Risk management options}

\subsubsection{Prior to drilling exploration}

Prior to drill pad construction, conceptual alternatives to reduce geohazard risks may include relocating the pad to reduce the spatial probability $(\mathrm{P}(\mathrm{S}: \mathrm{H}))$ and scaling/stabilising unstable slopes to reduce the hazard likelihood $(P(H))$. For example, risk can be reduced or eliminated by adjusting pad placement further from identified geohazards, or by deciding to relocate or to not develop a proposed site. Alternatively, if a site needs to be developed where currently planned, in the face of elevated risk, it may be possible to reduce a slope geohazard by stabilising a slope, carefully managing placement of fill, avoiding excavation into over-steepened slopes, avoiding directing surface runoff towards potentially unstable slopes, or in some cases (i.e. upslope landslides) by creating some form of debris barrier or containment bund. Sites located on active landslides can be managed with monitoring for differential movement and by establishing protocols with prescribed action for when movement accelerates, but the monitoring systems should be set up and tested before drilling activities begin.

\subsubsection{During drilling exploration}

Once a site has been selected and constructed, and is ready for use, risk can potentially be managed by changing the use and occupancy of the sites to reduce the temporal probability of the elements at risk $(\mathrm{P}(\mathrm{T}: \mathrm{S}))$, or by taking precautions appropriate for the specific site and its associated geohazards to reduce vulnerability or the number of exposed elements at risk. This may involve site-specific safe work practices (e.g. daily checks of upslope or downslope areas to look for seepage or signs of slope movement; Table 11), or monitoring (e.g. monitoring rainfall and/or streamflow conditions as part of a trigger action response plan (TARP)). It may also involve adjusting site occupancy to avoid use during higher hazard time periods or shortening the planned duration of operations to reduce exposure.

The physical characteristics of changing ground conditions can provide precursory evidence of an active or developing geohazard. Common observations are summarised in Table 11. Checking for these elements as part of daily workspace operation may provide advance notice of potential geohazard threats. 
Table 11 Precursory observations that may indicate an impending geohazard

\begin{tabular}{ll}
\hline Geohazard & Precursory observation \\
\hline Rockfall & Loose blocks upslope of site \\
& Blocks deposited near site \\
& Tree scars \\
Impact marks on ground & Dilated bedrock joints \\
& Fresh faces on bedrock outcrop \\
& Seismicity \\
Upslope landslide & Fresh debris on slope, in trees, in gullies \\
& Freshly exposed soil or rock \\
& Broken, damaged, or tilted vegetation \\
& Debris on pad \\
Scarps visible & Bulging or hummocky ground \\
Seepage & Seismicity \\
Flooding & Tension cracks on or near the pad \\
Pad crest settlement, sink holes or slumping \\
Water incising channels in pad \\
active landslide
\end{tabular}

Alongside noting physical observations, a geohazard TARP such as that in Table 12 and project-specific geohazard awareness training materials are valuable tools to educate workers of appropriate actions for managing geohazard risk. 
Table 12 Example geohazard trigger action response plan for exploration sites

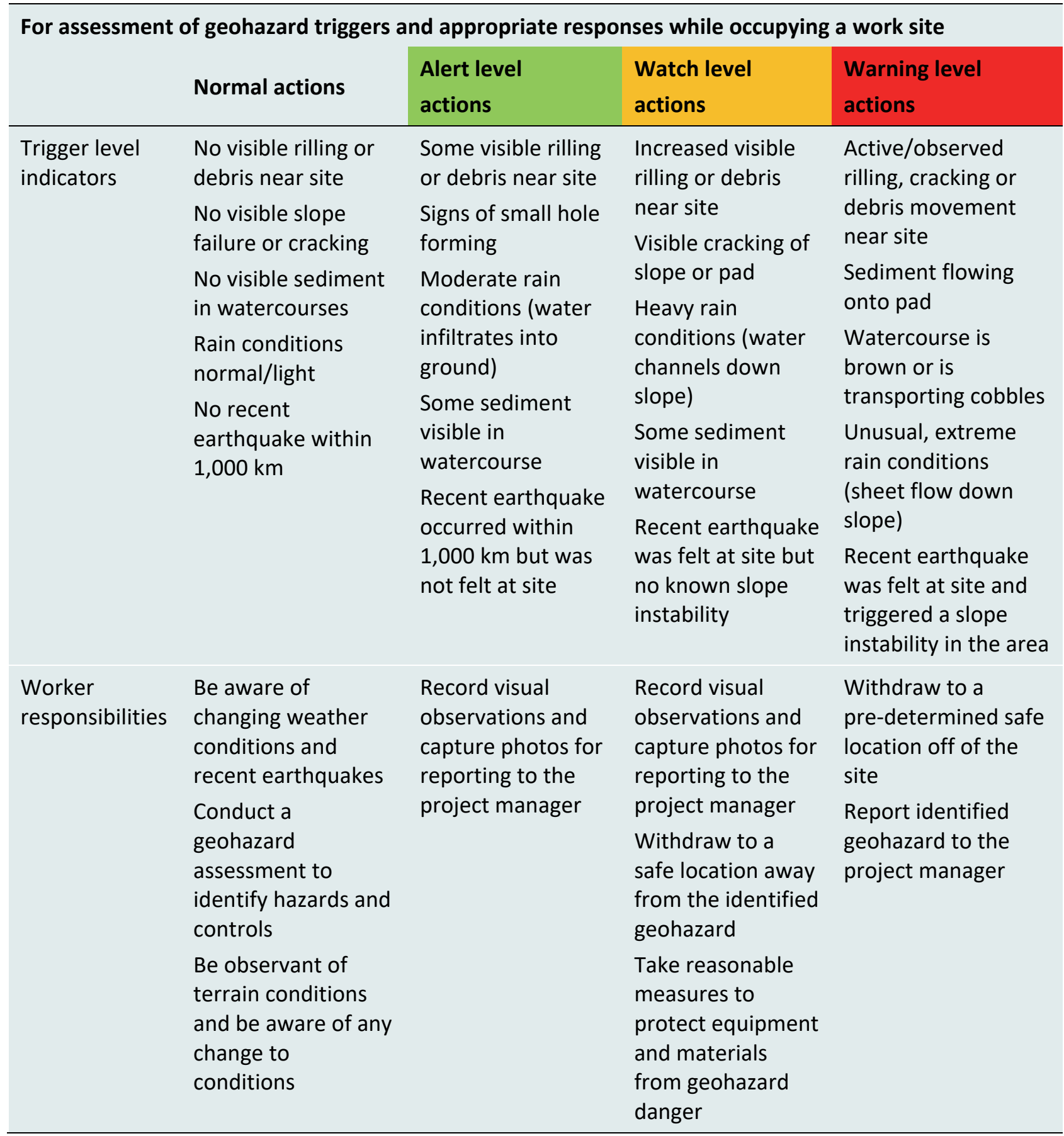

\section{$4 \quad$ Challenges}

A phased approach, with initial desktop screening and subsequent field assessment, allows the refinement of the geohazard risk assessment over time, with a reduction in uncertainty developing with the accumulation of new knowledge. Tropical environments inevitably have dense vegetation that limits the accuracy of desktop interpretation from satellite imagery and publicly available topography. The identification and characterisation of small, local features such as narrow steep creeks, tension cracks and rockfall deposits, or the differentiation of similar landforms, like active versus abandoned floodplains, can usually be completed with better confidence from the office using high-resolution imagery, including bare earth LiDAR topography. In all cases, however, interpretations are greatly improved by field reconnaissance. 
Site activities can significantly alter the potential for geohazard occurrence, and can create the potential for new or different types of geohazards to occur. For example, removal of tree cover will increase surface runoff and the potential for erosion and shallow landslides. Earthworks on pads, access roads and camp sites may over-steepen slopes by excavation or placement of loose fill, and may alter drainage patterns, which can redirect water to erodible or landslide-susceptible areas. These changes should be understood and anticipated during the field assessment, and in some cases may warrant further assessment during or following camp, access, and drill pad construction activities.

The methodology described herein is intended for the assessment and management of relatively high-probability geohazard scenarios that might originate at or within a few tens of metres from a work site. In very steep terrain with dense forest cover, even a careful field reconnaissance may not allow for the identification and characterisation of large, lower probability landslide hazards that may initiate hundreds of metres upslope of a work site. Owners and operational personnel should be aware of these limitations.

Warm temperatures and frequent precipitation are accompanied by ongoing weathering processes so that any surface geology assessment represents a snapshot in time. If site usage is significantly delayed, or if a major weather, earthquake or geohazard event occurs, a repeat field reconnaissance may be warranted prior to site usage.

\section{Conclusion}

This paper has presented a working example of geohazard risk assessment for mineral exploration activities at remote sites in rugged terrain and tropical environments. The approach was developed for a specific project site, with its own geologic, physiologic and climactic setting. Specific details, for example geohazard process types, can be easily adapted for similar activities in similar terrain with minimal adjustment to the methodology described herein.

In the authors' opinion, the main practical advantages of this system were that it was simple but robust. User calibration required relatively little effort; geohazard specialists and exploration geology professionals were mutually calibrated in use of the system after one or two days of field use. The outcomes, in terms of rated hazard, consequence and risk, were easy to understand, were based on clear, defensible logic that agreed with expert judgement, and served as a constructive basis for further planning and implementation of exploration activities.

\section{References}

Heim, A 1932, 'Landslides and human lives (Bergsturz and Menschenleben)', Beiblatt zur Vierteljahrsschrift der Naturforschenden Gesellschaft in Zürich, no. 20, vol. 77, translated by N Skermer.

Leroi, E, Bonnard, C, Fell, R \& McInnes, R 2005, 'Risk assessment and management', in O Hungr, R Fell, R Couture \& E Eberhardt (eds), Proceedings of the International Conference on Landslide Risk Management, A.A. Balkema, Rotterdam, pp. 159-198.

Morgenstern, N 1995, 'Managing risk in geotechnical engineering', Proceedings of the 10th Pan-American Conference on Soil Mechanics and Foundation Engineering, Mexican Society of Soil Mechanics, Mexico City, pp. 102-126.

Porter, M, Lato, M, Quinn, P \& Whittall, J 2019, 'Challenges with the use of risk matrices for geohazard risk management for resource development projects', in J Wesseloo (ed.), Proceedings of the First International Conference on Mining Geomechanical Risk, Australian Centre for Geomechanics, Perth, pp. 71-84. 